\title{
Label halal dan dampaknya terhadap pendapatan usaha Maha Bakery di
} Kota Pontianak

\author{
Rahmah Yulisa Kalbarini*, Reni Anggraini \\ Prodi Ekonomi Syariah, Fakultas Ekonomi dan Bisnis Islam, IAIN Pontianak, Pontianak 78121, \\ Indonesia.
}

\begin{abstract}
ABSTRAK
Penelitian ini memiliki tujuan yaitu: 1) Mengetahui pendapatan di toko Maha Bakery sebelum dan sesudah adanya label halal. 2) Untuk mengetahui apakah label halal berdampak pada harga produk di toko Maha Bakery. Metode penelitian dalam ini adalah kualitatif dengan menggunakan metode deskriptif. Teknik pengumpulan data dalam penelitian ini adalah observasi, wawancara dan dokumentasi. Kesimpulan dari penelitian ini ialah: 1) Pendapatan Maha Bakery sebelum adanya label halal ialah stabil. Kemudian setelah Maha Bakery mendapatkan label halal pendapatannya mengalami peningkatan. Adanya label halal pada produk Maha Bakery dapat meningkatkan kepercayaan konsumen pada produknya, sehingga berdampak pada tingkat penjualan dan pendapatannya. 2) Harga produk yang ditawarkan Maha Bakery kepada konsumen cukup terjangkau sehingga menarik minat konsumen. Setelah adanya label halal beberapa produk roti di Maha Bakery juga mengalami perubahan harga, namun kenaikan harga tersebut bukan disebabkan oleh adanya label halal MUI melainkan dikarenakan adanya bahan baku yang mengalami kenaikan harga.
\end{abstract}

Kata kunci: Harga Produk, Label Halal, Pendapatan.

C) 2022 Pusat Kajian Halal ITS. All rights reserved.

\section{Pendahuluan}

Islam mewajibkan setiap muslim untuk mengkonsumsi makanan dan minuman yang halal. Sebagaimana telah dijelaskan dalam surah Al-Baqarah ayat 168 Allah Swt. berfirman yang artinya: "Hai sekalian manusia, makanlah yang halal lagi baik dari apa yang terdapat dibumi, dan janganlah kamu mengikuti langkah-langkah setan. Karena sesungguhnya setan itu adalah musuh yang nyata bagimu" (Q.S. Al-Baqarah : 168).

Indonesia sebagai salah satu negara dengan jumlah penduduk muslim terbesar di dunia, yakni sebanyak 236,53 juta jiwa $(86,88 \%)$ dari total 272,23 juta jiwa pada Juni 2021 . Hal tersebut merupakan salah satu peluang besar bagi pengembangan industri halal khususnya di bidang makanan dan minuman halal. Makanan halal dan minuman halal dalam Masterplan Ekonomi Syariah adalah produk yang telah melalui proses sertifikasi halal yang ditandai dengan adanya logo halal pada kemasan. Bagi muslim, logo halal menandakan produk tersebut telah memenuhi ketentuan yang ditetapkan oleh hukum syariah sehingga layak dikonsumsi. Logo

\footnotetext{
* Corresponding author. Tel: +6285750515065; Fax: -.

Email address: rinikalbarini@yahoo.com
} 
halal bagi non muslim juga menandakan bahwa produk tersebut terjamin kebersihan, kualitas, kemurnian dan keamanan (Ambali dan Bakar, 2012 dalam masterplan ekonomi syariah).

Di Indonesia terdapat Lembaga Pengkajian Pangan Obat-obatan dan Kosmetika Majelis Ulama Indonesia (LPPOM MUI) yang memiliki tugas untuk mengkaji, meneliti, dan memutuskan apakah makanan dan minuman yang dikonsumsi baik untuk kesehatan dan halal dikonsumsi secara Islam. Oleh sebab itu LPPOM MUI mengeluarkan sertifikat Halal atau yang lebih dikenal dengan Label Halal MUI sebagai tanda bahwa makanan dan minuman tersebut sudah halal untuk dikonsumsi.

Namun ironinya, di Indonesia menurut data kompas.com dari 65 juta umkm yang ada, baru sekitar $1 \%$ atau 650.000 umkm yang mendapat sertifikat label halal MUI. Di Pontianak sendiri menurut data dari halalmuikalbar.or.id terdapat 100 perusahaan dan UMKM yang mencatatkan produknya dalam label halal MUI dari total 30.506 UMKM yang ada di Pontianak.

Salah satu UMKM yang memiliki label halal di bidang makanan adalah Maha Bakery. Maha Bakery merupakan bisnis yang bergerak dalam bidang makanan jenis roti. Bisnis roti atau bakery ini dirintis oleh Ibu Maha, dan sudah beroperasi selama 4 tahun. Maha Bakery adalah toko roti lokal yang ada di Pontianak yang memproduksi banyak jenis roti dan kue. Produk yang dihasilkan Maha Bakery berupa roti gandum, roti tawar, donat, kue ulang tahun dan masih banyak lagi jenis roti yang beraneka ragam yang dijual di Maha Bakery. Dari observasi yang peneliti lakukan, Maha Bakery memasarkan produknya melalui internet atau secara online seperti facebook, instagram dan whatsapp, yaitu melalui sistem rekapan melalui admin. Dan untuk masyarakat sekitaran Kota Pontianak bisa langsung datang ke toko. Maha Bakery juga mempunyai 6 reseller di daerah Kapuas Hulu yang mana para reseller memesan roti secara online.

Maha Bakery memulai usahanya pada tahun 2017. Pada tahun tersebut Maha Bakery belum memiliki label halal. Maha Bakery mulai mendaftarkan produknya untuk mendapatkan sertifikat label halal pada tahun 2018. Dampak yang dirasakan Maha Bakery setelah mendapatkan label halal berdampak pada harga dan pendapatan usaha. Berdasarkan latar belakang tersebut, peneliti tertarik untuk meneliti mengenai "Label Halal dan dampaknya terhadap pendapatan usaha Maha Bakery di Kota Pontianak.

Peneliti menggunakan beberapa penelitian terdahulu terkait label halal sebagai dasar melakukan penelitian ini. Adapun beberapa peneliti sebelumnya adalah penelitian dengan judul Pengaruh Label Halal Terhadap Pendapatan Agroindustri Obat Tradisional Dan Tanaman Rempah Di Madura yang dilakukan oleh Sulastri pada tahun 2021, penelitian dilatarbelakangi oleh adanya potensi pengembangan agroindustry dan tanaman rempah di Kabupaten Madura sehingga perlu adanya label halal pada setiap obat tradisional dan tanaman rempah. Penelitian menggunakan penelitian kuantitatif dengan hasil penelitian adanya pengaruh positif antara label halal dan pendapatan agroindustri. Persamaan dengan penelitian yang peneliti lakukan adalah sama-sama membahas mengenai label halal dan perbedaannya adalah penelitian yang dilakukan oleh Sulastri membahas pengaruhnya terhadap pendapatan agrobisnis dengan metode penelitian kuantitatif sedangkan penelitian ini membahas dampak 
dari adanya label halal terhadap pendapatan salah satu UMKM di bidang kuliner dengan menggunakan metode penelitian kualitatif [1].

Penelitian terdahulu berikutnya adalah peneltian yang dilakukan oleh Nurjanah dan Rizal Baiti pada tahun 2020 dengan judul Dampak Label Syariah terhadap Pendapatan Pada Usaha Jasa di Kota Langsa. Penelitian ini membahas mengenai dampak label syariah pada pendapatan usaha dibidang jasa yang dalam hal ini adalah usaha laundry. Penelitian menggunakan metode kualitatif dengan teknik interaktif dan komparasi. Hasil yang didapat label syariah berpengaruh terhadap pendapatan namun tidak begitu signifikan karena konsumen memilih usaha laundry berdasarkan pertimbangan lain seperti kualitas pelayanan, lokasi dan lain-lain. Persamaan dengan yang peneliti lakukan adalah sama-sama membahas mengenai label syariah atau label halal dan kaitannya dengan pendapatan usaha. Perbedannya adalah penelitian yang peneliti lakukan terfokus pada pendapatan usaha dibidang kuliner khususnya bakery dan dikatikan dengan harga [2].

\section{Kajian pustaka dan metode penelitian}

\subsection{Kajian pustaka}

Label halal merupakan label yang memberikan informasi kepada konsumen tentang suatu produk dimana produk tersebut memiliki kandungan baik dan terbebas dari hal-hal yang dilarang oleh syariat sehingga produk tersebut aman. Produk makanan yang tidak mempunyai label halal dianggap masih memiliki kandungan atau zat-zat yang dilarang oleh syariat sehingga produk tersebut masih diragukan [3].

Labelisasi halal mencakup keseluruhan proses produk dimulai dari proses pembuatan produk harus terhindar dari bahan-bahan yang dilarang oleh syariat, pengemasan produk harus terjamin kebersihannya, penyimpanan produk dilakukan dengan aman, hingga pendistribusian barang sampai kepada konsumen. Label halal merupakan pencantuman tulisan atau logo yang berisi pernyataan halal untuk memberikan informasi bahwa produk yang dimaksud adalah produk halal secara syariat dan aman untuk dikonsumsi[4]. Adapun proses untuk mendapat label halal adalah melalui sertifikat halal. Sertifikat halal adalah suatu fatwa yang ditulis oleh otoritas yang mendapat berwenang yang dalam hal ini adalah Majelis Ulama Indonesia (MUI). Sertifikat halal ini merupakan syarat untuk pencantuman label halal pada produk kemasan.

Lembaga Pengkajian Pangan Obat-obatan dan Kosmetika Majelis Ulama Indonesia atau yang sering disingkat LPPOM MUI adalah lembaga yang diberikan kewenangan dalam proses sertifikasi halal. Adapun tugas LPPOM MUI adalah untuk meneliti sekaligus mengkaji dan menganalisa produk-produk baik makanan ataupun minuman, obat-obatan bahkan kometika sebelum memutuskan apakah produk-produk aman dikonsumsi baik dari sisi kesehatan dan dari sisi hukum Syariat.

Ada beberapa aspek yang menjadi tinjauan dalam labelisasi halal [5], yaitu:

1. Proses pembuatan produk harus memperhatikan hal-hal berikut:

a. Binatang yang menjadi bahan dasar hendaknya yang bersih dan disembelih sesuai dengan ketentuan syariat.

b. Bahan campuran produk yang digunakan harus halal dan tidak terbuat dari bahanbahan yang haram. 
c. Air yang digunakan dalam proses produksi haruslah air yang bersih dan terbebas dari bahan-bahan kimia lainnya.

d. Dalam proses produksi hendaknya bahan produksi dan lainnya tidak tercampur atau bahkan berdekatan dengan barang atau bahan yang najis atau haram.

2. Bahan baku utama haruslah bahan baku yang sudah terjamin kehalalannya baik dari bentuk maupun proses mendapatkannya.

3. Bahan pembantu atau bahan penolong adalah bahan yang berfungsi untuk membantu mempercepat proses produksi. Bahan pembantu juga haruslah terjamin kehalalannya.

4. Efek makanan halal tidak boleh terlepas dari tujuan syariat Islam yaitu mengambil maslahat dan menolak mudhorot atau bahaya. Maksudnya jika menurut kesehatan suatu jenis makan dapat membahayakan kesehatan seseorang, maka makanan tersebut haram untuk dikonsumsi. Pengadaan sertifikasi halal bertujuan untuk memberikan kepastian kehalalan suatu produk sehingga produk tersebut dapat dikonsumsi oleh konsumen muslim.

Pendapatan adalah segala sesuatu yang diterima seseorang baik berupa harta ataupun lainnya sebagai tanda hasil usaha atau pekerjaan yang dilakukan [6]. Pendapatan merupakan hasil dari usaha atau pekerjaan yang diterima oleh seseorang atau rumah tangga [7]. Secara umum pendapatan merupakan penghasilan yang diterima oleh masyarakat berdasarkan kinerjanya baik berupa pendapatan uang maupun bukan uang yang dihitung dalam jangka waktu tertentu sesuai dengan kesepakatan.

Pada dasarnya pendapatan yang diterima oleh seseorang dipengaruhi oleh beberapa factor seperti banyaknya pengalaman dan tingkat pendidikan seseorang, semakin banyaknya pengalaman dan tingginya tingkat pendidikan maka makin tinggi pula tingkat pendapatannya. Selain itu, tingkat pendapatan dipengaruhi oleh besarnya modal kerja, jam kerja yang dilakukan oleh pekerja, jumlah tenaga kerja di suatu perusahaan atau badan tertentu, tanggungan keluarga pekerja, dan faktor lainnya[7].

Faktor yang mempengaruhi tingkat pendapatan pedagang [8], yaitu :

a. Kemampuan pedagang dalam berdagang, yaitu kemampuan seorang pedagang menjual barang atau jasa yang dimilikinya.

b. Kondisi pasar, yang berkaitan dengan keadaan pasar pada saat itu, jenis pasar yang dipilih oleh pedagang, kelompok pembeli di suatu pasar, lokasi dalam berdagang, frekuensi pembeli dalam membeli barang serta selera pembeli.

c. Modal sangat penting untuk diperhatikan oleh pedagang karena modal merupakan harta awal yang dimiliki oleh pedagang. Modal dapat menentukan seberapa besar kemampuan pedagang dalam berdagang. Jika ingin meningkatkan keuntungan dalam penjualan maka modal haruslah besar.

d. Kondisi organisasi usaha, jika suatu pedagang mampu mengelola organisasi usahs dengan baik maka diharapkan dapat memiliki frekuensi penjualan yang tinggi dan berdampak pada keuntungan yang meningkat.

e. Faktor lain yang mendukung dalam usaha atau berdagang seperti media promosi dalam mempromosikan produk dan lainnya.

Harga adalah sejumlah uang atau nilai yang dimiliki atas suatu produk dan jasa yang dapat ditukarkan para konsumen untuk memperoleh hasil atau manfaat dari menggunakan atau memiliki produk atau jasa tersebut [9]. Harga adalah salah satu faktor yang dapat 
mempengaruhi pilihan seorang pembeli untuk menentukan barang atau jasa yang hendak dikonsumsi atau dipergunakan [10]. Indikator harga [11], yaitu:

a. Keterjangkauan Harga. Jika harga yang ditawarkan terjangkau menurut konsumen maka dapat dipastikan konsumen tersebut akan membeli atau menggunakan barang atau jasa yang ditawarkan.

b. Kesesuaian harga dengan kualitas produk. Pada dasarnya konsumen senang membandingkan harga dengan kualitas yang diberikan. Tak jarang konsumen memilih membeli produk dengan harga yang mahal jika kualitas produk tersebut dirasa bagus oleh konsumen.

c. Daya saing harga. Daya saing harga berkaitan dengan persaingan pasar. Banyak perusahaan yang menetapkan harga jual produk dengan memperhatikan harga jual di pasaran.

d. Kesesuaian harga dengan manfaat. Sama seperti kualitas, tak jarang konsumen membandingkan harga dengan manfaat yang akan didapat ketika mengkonsumsi atau menggunakan barang tersebut.

\subsection{Metode penelitian}

Jenis penelitian ini adalah penelitian kualitatif deskriptif dimana peneliti berusaha untuk memecahkan atau menjawab persoalan yang sedang dihadapi pada keadaan yang ada. Adapun permasalahan tersebut yaitu berkaitan dengan label halal dan dampaknya pada pendapatan usaha Maha Bakery. Penelitian ini menggunakan data primer dan data sekunder. Adapun data primer yang dimaksud adalah observasi yang dilakukan kepada subyek penelitian yaitu usaha Maha Bakery yang dilanjutkan dengan wawancara kepada pihak yang berkepentingan yaitu pemilik, karyawan dan konsumen yang ada di Maha Bakery. Data sekunder dalam penelitian ini berupa dokumen lain terkait dengan penelitian seperti buku, artikel, dan laporan usaha Maha Bakery.

Teknik analisis data dalam penelitian ini adalah pengumpulan data kemudian mereduksi data yang tidak sesuai dengan penelitian. Setelah itu melakukan penyajian data dan penarikan kesimpulan. Teknik keabsahan data dalam penelitian ini adalah triangulasi data di mana peneliti mencocokkan kembali jawaban yang diberikan oleh pemilik usaha kepada karyawan dan konsumen di Maha Bakery.

\section{Hasil dan diskusi}

\subsection{Hasil}

Adapun hasil penelitian yang didapatkan adalah Pendapatan usaha Maha Bakery sebelum dan sesudah adanya label halal diukur melalui 3 aspek yaitu:

\section{a. Pendapatan}

Berdasarkan hasil wawancara peneliti dengan Ibu Maha, selaku owner Maha Bakery, didapatkan bahwa pendapatan Maha Bakery sebelum adanya label halal cenderung stabil, sedangkan pendapatan Maha Bakery setelah adanya label halal mengalami peningkatan. Peningkatan itu terjadi adanya peningkatan kepercayaan konsumen pada produk Maha Bakery yang sudah memiliki label halal. 
Pernyataan ibu Maha didukung oleh pernyatan karyawan Maha Bakery yang menyatakan adanya peningkatan penjualan sebesar $12 \%$. Hal ini disebabkan oleh peningkatan kepercayaan konsumen terhadap produk Maha Bakery.

b. Modal selain pendapatan

Dalam suatu usaha, yang paling pertama dan perlu diperhatikan salah satunya adalah modal awal usaha. Pada awalnya ibu Maha selaku pemilik Maha Bakery menggunakan modal sendiri bersama dengan suami untuk membangun usaha Maha Bakery tanpa pinjaman baik dari bank ataupun lembaga keuangan lainnya. Pernyataan ini didukung oleh pernyataan karyawan yang menyebutkan bahwa tidak ada pinjaman kepada bank ataupun lembaga keuangan lain dalam menjalankan usaha Maha Bakery ini.

c. Jenis-jenis produk

Maha Bakery menyediakan berbagai macam jenis roti, di antaranya adalah roti, kue kering, kue basah, donat, dan kue ulang tahun dengan berbagai varian rasa. Dengan keanekaragaman produk yang dijual dapat meningkatkan pendapatan Maha Bakery. Pernyataan Ibu Maha ini didukung oleh karyawan yang menyatakan bahwa banyak varian jenis roti yang dijual di Maha Bakery. Bahkan Maha Bakery menerima pesanan kue untuk berbagai acara. Banyaknya variasi membuat banyak pilihan kepada konsumen sehingga diharapkan dapat meningkatkan pendapatan.

Adapun dampak label halal terhadap harga produk diukur berdasarkan :

a. Harga produk

Harga produk di Maha Bakery berdasarkan HPP (Harga Pokok Penjualan). Menurut Ibu Maha kenaikan harga di Maha Bakery disebabkan oleh adanya kenaikan harga bahan baku dan biaya lainnya. Sedangkan label halal tidak berpengaruh kepada kenaikan harga produk di Maha Bakery. Sertifikasi label halal tidak dibebankan kepada konsumen karena untuk mengurus sertifikasi halal, Maha Bakery mendapat subsidi dari Bank Indonesia dan MUI. Pernyataan ini didukung oleh karyawan Maha Bakery yang menyatakan bahwa kenaikan harga produk hanya disebabkan oleh kenaikan bahan baku mulai dari tepung, telur dan lain-lain. Selain itu pernyataan ini juga didukung oleh salah satu konsumen Maha Bakery yang menyatakan bahwa harga roti di Maha Bakery tergolong murah dan cocok dikantong mereka.

b. Keterjangkauan harga produk

Harga produk di Maha Bakery sangat terjangkau dikarenakan pemilik Maha Bakery menjual berdasarkan HPP dan mengambil keuntungan sedikit di atas HPP. Pernyataan ini didukung oleh karyawan Maha Bakery yang menyatakan bahwa banyaknya produk yang dijual dengan berbagai variasi harga membuat roti maha bakery terjangkau bagi semua kalangan. Konsumen Maha Bakery juga menyatakan bahwa produk di Maha Bakery terjangkau untuk semua kalangan dikarenakan banyak varian produk dengan varian harga yang berbeda pula.

c. Kesesuaian harga dengan kualitas 
Selain harga, kualitas produk Maha Bakery juga bagus. Hal ini terlihat dari penggunaan bahan baku dan teknologi dalam memproduksi roti di Maha Bakery. Pernyataan ini juga didukung oleh karyawan Maha Bakery yang menyatakan bahwa Maha Bakery sangat menjamin kualitas produknya. Hal ini terlihat mulai dari pemilihan baku, penggunaan alat masak yang bersih hingga pengemasan roti yang bersih. Salah satu konsumen Maha Bakery juga menyatakan bahwa harga produk di Maha Bakery sesuai dengan kualitas cita rasa roti yang ditawarkan.

\section{d. Daya saing}

Pelaku usaha di bidang bakery sudah sangat banyak kita temui. Agar Maha Bakery bisa bersaing dengan produk-produk lain, Maha Bakery melakukan beberapa inovasi. Beberapa inovasi yang dilakukan adalah menggunakan kearifan lokal seperti membuat roti dengan bahan ubi talas, membuat kue talas, roti ubi rambat, dan juga membuat produk dengan ciri khas Pontianak. Konsumen Maha Bakery juga menyatakan bahwa walaupun banyak toko roti yang ada di Pontianak, mereka tetap memilih Maha Bakery karena rasanya yang enak, harga yang terjangkau, dan sudah ada label halalnya.

\subsection{Pembahasan}

Adapun pembahasan mengenai Pendapatan Pengusaha di Toko Maha Bakery Sebelum dan Sesudah Adanya Label Halal adalah:

\section{a. Pendapatan}

Pendapatan merupakan segala sesuatu yang diterima sebagai imbal jasa atas hasil atau usaha yang dilakukan atau dijual [6]. Pendapatan juga dapat diartikan sebagai imbalan atas faktorfaktor produksi kerja, baik sumber daya alam, sumber daya manusia maupun modal dengan mengurangi biaya-biaya yang ada [12]. Pendapatan Maha Bakery sebelum adanya label halal ialah stabil, maksudnya adalah tetap dan tidak mengalami kenaikan. Hal ini bisa dilihat dari segi penetapan harga produk, penjualan, pendapatan, dan pengelolaan lainnya berjalan dengan baik. Pendapatan Maha bakery setelah adanya label halal mengalami peningkatan. Peningkatan itu terjadi karena adanya kepercayaan dari konsumen mengenai kehalalan produk tersebut. Lebih lanjut pendapatan Maha Bakery meningkat sebesar $12 \%$.

b. Modal atau modal usaha

Modal adalah uang atau harta pokok yang dikeluarkan pedagang untuk berdagang yang dapat dipergunakan untuk menghasilkan sesuatu produk yang menambah kekayaan pedagang [13]. Pada awal membuka bisnis bakery ini, Maha Bakery menghabiskan modal sekitar 100 juta. Modal tersebut digunakan untuk menyewa kios, membeli alat-alat untuk pembuatan bakery dan membeli keperluan yang lainnya. Modal yang digunakan diperoleh dari tabungan pemilik dan suami.

c. Jenis-jenis produk.

Produk merupakan apa saja yang dibutuhkan dan diinginkan oleh seorang konsumen untuk memenuhi kebutuhan dan keinginannya [14]. Produk adalah segala sesuatu yang dihasilkan oleh perusahaan dengan memiliki berbagai keunggulan yang diharapkan dapat bersaing dipasar. Setiap harinya Maha Bakery memproduksi ratusan roti dengan berbagai macam jenis 
roti yang berbeda-beda. Dengan banyaknya jenis roti yang tersedia di Maha Bakery, mereka juga mempunyai beberapa produk best seller seperti roti sisir, roti jambul khatulistiwa, donat dan masih banyak produk roti yang lainnya sehingga dapat meningkatkan pendapatan.

Dari pembahasan ini dapat disimpulkan bahwa kenaikan pendapatan Maha Bakery secara tidak langsung disebabkan oleh label halal. Dengan adanya label halal, maka kepercayaan konsumen meningkat sehingga menyebabkan kenaikan pada penjualan dan berdampak pada kenaikan pendapatan usaha Maha Bakery.

Adanya Label Halal berpengaruh pada harga produk di Maha Bakery dapat dilihat dari beberapa indikator yaitu:

a. Harga adalah sejumlah uang atau nilai yang dimiliki atas suatu produk dan jasa yang dapat ditukarkan para konsumen untuk memperoleh hasil atau manfaat dari menggunakan atau memiliki produk atau jasa tersebut. Menurut Andi (2015) dalam [10], harga adalah salah satu faktor yang dapat mempengaruhi pilihan seorang pembeli untuk menentukan barang atau jasa yang hendak dikonsumsi atau dipergunakan [15]. Harga produk roti Maha Bakery tergolong murah sehingga menarik minat konsumen untuk membeli produk tersebut. Label halal tidak langsung berdampak terhadap kenaikan harga di Maha bakery dikarenakan pembuatan label halal MUI yang mendapat subsidi dari MUI dan BI sehingga tidak dibebankan kepada harga produk Maha Bakery. Adapun kenaikan harga dari produk Maha Bakery disebabkan oleh kenaikan bahan baku.

b. Keterjangkauan Harga adalah harga sebenarnya dari suatu produk, yang harus dibayarkan oleh konsumen Tjiptono dalam [16]. Seperti halnya produk yang ditawarkan Maha Bakery kepada konsumen harganya cukup terjangkau dan tidak memberatkan konsumen. Selain harganya yang terjangkau beberapa konsumen juga mengatakan bahwa rasa roti di Maha Bakery enak dan memilki banyak varian rasa. Apalagi Maha Bakery sudah mempunyai label halal MUI, konsumen semakin yakin untuk membeli produknya.

c. Kesesuaian Harga Dengan Kualitas. Kualitas produk adalah keseluruhan ciri suatu produk atau pelayanan yang bertujuan untuk memuaskan kebutuhan konsumen [11]. Konsumen akan merasa puas bila hasil pengamatan terhadap produk tersebut menyatakan bahwa produk yang konsumen miliki atau gunakan berkualitas [17]. Kualitas produk di Maha Bakery mereka menggunakan bahan-bahan yang mempunyai kualitas sangat baik. Maha bakery juga telah mempunyai label halal MUI pada produknya yang mengindikasikan bahwa bahan-bahan baku yang digunakan dalam produk Maha Bakery memiliki kualitas yang baik dan terjamin kehalalannya. Salah satu Konsumen Maha Bakery juga menyatakan bahwa harga roti sudah sesuai dengan kualitas dan cita rasa roti Maha Bakery. Selain itu adanya label halal menambah keyakinan konsumen terhadap kualitas roti Maha Bakery.

Dari pembahasan tersebut dapat disimpulkan bahwa kenaikan harga pada produk Maha Bakery tidak disebabkan oleh adanya label halal namun disebabkan kenaikan bahan baku. Keterjangkauan harga, kesesuaian harga dengan kualitas dan adanya label halal membuat produk Maha Bakery semakin digemari oleh masyarakat dan meningkatkan pendapatan Maha Bakery. 


\section{Kesimpulan}

Simpulan yang didapat dalam penelitian ini adalah :

1. Pendapatan Maha Bakery sebelum adanya label halal ialah stabil dimana dalam penetapan harga produk, penjualan, pendapatan pengelolaan yang lainnya berjalan dengan baik. Kemudian setelah Maha Bakery mencatatkan merek produknya di MUI dan mendapatkan sertifikat halal pendapatannya mengalami peningkatan. Peningkatan pendapatan itu terjadi meningkatnya kepercayaan konsumen pada produk Maha Bakery, sehingga penjualan meningkat sehingga berdampak pada pendapatannya.

2. Harga produk yang ditawarkan Maha Bakery cukup terjangkau dan sesuai dengan kualitas yang diberikan sehingga menarik minat konsumen untuk membeli produk Maha Bakery. Setelah adanya label halal beberapa produk roti di Maha Bakery tidak mengalami perubahan. Hal ini dikarenakan biaya untuk mengurus sertifikasi label halal Maha Bakery mendapat subsidi dari Bank Indonesia dan MUI sehingga sertifikasi label halal tidak dibebankan kepada konsumen.

\section{Ucapan terima kasih}

Penelitian ini takluput dari bantuan beberapa pihak yang membantu dalam penelitian ini. Ucapan terima kasih ditunjukkan kepada para Pimpinan IAIN Pontianak yang telah memberikan izin kepada peneliti untuk menyelesaikan penelitian ini. Pimpinan Fakultas Ekonomi dan Bisnis IAIN Pontianak yang telah memberikan dukungan moril kepada peneliti dalam menyelesaikan penelitian ini.

Tak lupa pula peneliti mengucapkan terima kasih kepada pihak Maha Bakery yang telah memberikan izin untuk melakukan penelitian di Maha Bakery, kepada pemilik usaha Maha Bakery beserta karyawan Maha Bakery yang telah memberikan data-data terkait dengan penelitian. Ucapan terima kasih juga diberikan kepada para konsumen Maha Bakery yang bersedia peneliti wawancarai guna mendukung kelengkapan data terkait dengan penelitian ini.

\section{Referensi}

[1] B. A. S. B. A. Sulastri, "Pengaruh Label Halal Terhadap Pendapatan Agroindustri Obat Tradisional Dan Tanaman Rempah Di Madura," Qawwam Leader's Writ., vol. 2, no. 2, pp. 169-205, 2021.

[2] R. Zuliani, "Dampak Label Syariah Terhadap Pendapatan Pada Usaha Jasa Di Kota Langsa," 2020.

[3] Mahwiyah, "Pengaruh Label Halal Terhadap Keputusan Pembelian (Studi Kasus Pada Dosen Fakultas Syariah Dan Hukum Uin Jakarta)", UIN Jakarta, 2010.

[4] R. Yuli, "Analisis Komparatif Labelisasi Halal Pada Kosmetik Dalam Meningkatkan Minat Beli Masyarakat Di Kecamatan Syiah Kuala Dan Kecamatan Kuta Alam," Uin Ar-Raniry, 2019.

[5] M. Darma, "Sanksi Produk Yang Tidak Berlabel Halal," J. Ekon. Dan Keungan Publik, vol. 2, no. 2, 2020.

[6] S. Zulaicha dan R. Irawati, "Pengaruh Produk Dan Harga Terhadap Keputusan Pembelian Konsumen Di Morning Bakery Batam," Inovbiz J. Inov. Bisnis, 2016, Doi: 10.35314/Inovbiz.V4i2.76. 
[7] Nazir, "Analisis Determinan Pendapatan Pedagang Kaki Lima Di Kabupaten Aceh Utara," Tesis, 2010.

[8] B. Swastha, "Manajemen Pemasaran Modern". 2008.

[9] Amstrong dan Kotler, "Manajemen Pemasaran," Kotler Amstrong 2012, 2012.

[10] A. Bindas, "Analisis Pengaruh Harga (Price), Tempat (Place) Dan Promosi (Promotion) Terhadap Kepuasan Konsumen (Customer Satisfaction) ...," Juti Unisi, 2020.

[11] P. Kotler dan G. Amstrong, "Prinsip-Prinsip Pemasaran, Jilid 1.," Manajemen Pemasaran. 2008.

[12] A. Syahma, "Analisis Faktor-Faktor Yang Mempengaruhi Pendapatan Nelayan Tangkap Di Desa Galesong Kota Kecamatan Galesong Kabupaten Takalar," 2016.

[13] L. A. Nugroho, "Pengaruh Modal Usaha". Yogyakarta: Pustaka Pelajar, 2011.

[14] N. Supranto dan Limakrisna, "Perilaku Konsumen Dan Strategi Pemasaran", 2011.

[15] P. Kotler, "Kotler On Marketing," Kotler On Marketing. 2012.

[16] C. E. Ferdinan dan R. Nugraheni, "Analisis Pengaruh Persepsi Harga, Persepsi Kualitas Produk, Dan Promosi Terhadap Keputusan Pembelian Sepeda Motor Suzuki (Studi Pada Pembeli - Pengguna Sepeda Motor Suzuki Di Kota Solo)," Diponegoro J. Manag., 2013.

[17] R. Lupiyoadi, "Manajemen Pemasaran Jasa: Berbasis Kompetensi Edisi 3," Penerbit Salemba, 2013. 